Article

\title{
Strip Tillage and Early-Season Broadleaf Weed Control in Seeded Onion (Allium cepa)
}

\author{
Sarah Gegner-Kazmierczak and Harlene Hatterman-Valenti \\ Department of Plant Sciences, North Dakota State University, PO Box 6050, Dept. 7670, Fargo, \\ ND 58108-6050, USA; s.gegner1@gmail.com \\ * Correspondence: h.hatterman.valenti@ndsu.edu \\ Academic Editor: Les Copeland \\ Received: 28 October 2015; Accepted: 9 March 2016; Published: 24 March 2016
}

\begin{abstract}
Field experiments were conducted in 2007 and 2008 near Oakes, North Dakota (ND), USA, to evaluate if strip tillage could be incorporated into a production system of seeded onion (Allium cepa) to eliminate the standard use of a barley (Hordeum vulgare) companion crop with conventional, full width tillage, yet support common early-season weed control programs. A split-factor design was used with tillage (conventional and strip tillage) as the main plot and herbicide treatments (bromoxynil, DCPA, oxyfluorfen, and pendimethalin) as sub-plots. Neither tillage nor herbicide treatments affected onion stand counts. Common lambsquarters (Chenopodium album) densities were lower in strip tillage compared to conventional tillage up to three weeks after the post-emergence applied herbicides. In general, micro-rate post-emergence herbicide treatments provided greater early-season broadleaf weed control than pre-emergence herbicide treatments. Onion yield and grade did not differ among herbicide treatments because the mid-season herbicide application provided sufficient control/suppression of the early-season weed escapes that these initial weed escapes did not impact onion yield or bulb diameter. In 2007, onion in the strip tillage treatment were larger in diameter resulting in greater total and marketable yields compared to conventional tillage. Marketable onion yield was $82.1 \mathrm{Mg} \mathrm{ha}^{-1}$ in strip tillage and $64.9 \mathrm{Mg} \mathrm{ha}^{-1}$ in conventional tillage. Results indicate that strip tillage use in direct-seeded onion production was beneficial, especially when growing conditions were conducive to higher yields and that the use of strip tillage in onion may provide an alternative to using a companion crop as it did not interfere with either early-season weed management system.
\end{abstract}

Keywords: common lambsquarters (Chenopodium album); redroot pigweed (Amaranthus retroflexus); hairy nightshade (Solanum physalifolium); herbicide reduced rates; reduced tillage

\section{Introduction}

Onion (Allium cepa) is the fifth most-valuable vegetable crop produced and the third largest fresh vegetable industry in the United States with an annual crop value of almost one billion dollars direct from the field [1,2]. It is an intensively managed crop characterized by slow emergence, poor competitive morphology, and limited early-season weed management options, which means that yields can fall within a wide range depending on the cultivation conditions and the degree of weed control $[3,4]$. When seed are sown directly into the ground a well-prepared field is required as any stress to onion can negatively affect bulbing and yield [5]. Other factors that may influence onion yield and quality include planting date, plant spacing, soil moisture, and damage from blowing soil, insects, or diseases.

High winds in North Dakota may remove seed from the rows or damage newly emerged onion seedlings [6]. To reduce damage to onion from blowing soil particles, growers plant barley (Hordeum vulgare) as a companion crop. Barley emerges quickly in comparison to onion, but this also 
complicates weed management strategies since growers do not want to reduce barley germination, but must kill the barley before it reaches a height of $18 \mathrm{~cm}$ and competes with the onion crop reducing onion yield [7].

In a reduced tillage system or a low disturbance tillage system at least $30 \%$ of the soil surface remains covered by residue compared to conventional, full-width tillage [8]. Strip tillage is a form of conservation tillage, which disturbs only the crop rows while the rest of the soil remains undisturbed. As a result, soil losses by wind and water erosion are reduced by $25 \%$ to $30 \%$. Residue on the soil surface may also reduce weed seedling emergence by allelopathic and shading effects or by intercepting herbicide applications [9]. Strip tillage is an emerging practice in vegetable production as it offers advantages of less erosion and maintained soil quality compared with conventional tillage [10].

Weed control is a vital component in the production of marketable onion. However, herbicide application restrictions and limited weed control spectra with pre-emergence herbicides (PRE) make early-season broadleaf weed control in seeded onion difficult. This is further complicated when a barley companion crop is planted as previously described. Recent research has shown effective early-season broadleaf weed control can be achieved by applying post-emergence (POST) herbicides at regular intervals as micro-rates when broadleaf weeds are in the cotyledon to first-true-leaf stage [11]. These applications have been effective in standard tillage systems, but have not been tested in strip tillage systems. The objective of this research was to determine if strip tillage could be used instead of standard tillage practices in seeded onion when various early-season (prior to onion two-leaf growth stage) weed control options were used.

\section{Materials and Methods}

Field experiments were conducted at the Oakes Research Extension Center near Oakes, ND, in 2007 on an Embden loam and in 2008 on a Hecla sandy loam with a previous crop of hard red spring wheat (Triticum aestivum) each year. A split-factor design was used with tillage as the main plot and herbicide treatments as sub-plots, replicated four times. Individual plots were four paired-rows of 'Teton' (Petoseed Co., Santa Maria, CA, USA) onion with main rows measuring $40.6 \mathrm{~cm}$ from center-to-center and $6.4 \mathrm{~cm}$ between each pair.

\subsection{Tillage and Herbicide Treatments}

Conventional and strip tillage treatments were conducted 15 October 2007 and 13 October 2008. Conventional or non-inversion tillage consisted of two passes of a field cultivator that disturbed the soil to an average depth of $30 \mathrm{~cm}$. In 2008, the conventional tillage treatment required an additional field cultivator pass 21 April to reduce soil clods and create a suitable seedbed. Strips for the strip tillage treatment were made using a strip tiller (Maverick; Yetter Manufacturing Inc., Colchester, IL, USA) equipped with coulters. Strips were $15.2 \mathrm{~cm}$ wide and tilled to a depth of 15 to $20 \mathrm{~cm}$.

Herbicide treatments included PRE herbicides DCPA (Dacthal W-75; AMVAC Chemical Corporation, Los Angeles, CA, USA) or pendimethalin (Prowl $\mathrm{H}_{2} \mathrm{O}$; BASF Corporation, Research Triangle Park, NC, USA) and POST herbicides bromoxynil (Buctril; Bayer CropScience, Research Triangle Park, NC, USA) or oxyfluorfen (GoalTender; Dow AgroSciences, Indianapolis, IN, USA). For comparison two checks: the standard grower practice for weed control and a hand-weeded check were included. The standard grower practice for weed control consisted of DCPA applied PRE at $11.2 \mathrm{~kg}$ ai ha ${ }^{-1}$. Weekly hand-weeding began once the onion row could be seen. The other DCPA treatment examined the lowest herbicide rate on the label. DCPA and pendimethalin were applied one week after planting at $8.4 \mathrm{~kg} \mathrm{ha}^{-1}$ and $0.8 \mathrm{~kg}_{\text {ai ha }}-1$, respectively. POST herbicides were applied at micro-rates, which consisted of four weekly applications at $70.1 \mathrm{~g} \mathrm{ha}^{-1}$, which corresponded to 0.25 and 0.5 times the lowest labeled rate for bromoxynil and oxyfluorfen, respectively. Micro-rate applications began when broadleaf weeds reached the cotyledon to one-true-leaf stage, which corresponded to the loop-stage for onion both years. An overview of the herbicide treatments and timings are shown in Table 1. $\mathrm{A} \mathrm{CO}_{2}$-pressurized backpack sprayer was used to make all micro-rate treatment applications. 
The backpack sprayer was equipped with TeeJet 8002 flat-fan nozzles (Spraying Systems Co., Chicago, IL, USA) spaced at $45.7 \mathrm{~cm}$ along a $1.5-\mathrm{m}$-wide boom, which sprayed four paired-rows at a time and was calibrated to deliver $187 \mathrm{~L} \mathrm{ha}^{-1}$.

Table 1. Pre- and post-emergence herbicide application rates and timings at Oakes, ND, USA in 2007 and 2008.

\begin{tabular}{|c|c|c|c|c|c|}
\hline \multirow{2}{*}{ Treatment } & \multirow{2}{*}{ Rate } & \multicolumn{4}{|c|}{ Date of Application } \\
\hline & & 1 & 2 & 3 & 4 \\
\hline Oakes 2007 & g ai ha ${ }^{-1}$ & & & & \\
\hline \multicolumn{6}{|l|}{ Pre-emergence } \\
\hline DCPA & 8405 & 30 April & & & \\
\hline Pendimethalin & 798.6 & 30 April & & & \\
\hline \multicolumn{6}{|l|}{ Post-emergence } \\
\hline Bromoxynil & 70.1 & 16 May & 23 May & 31 May & 6 June \\
\hline Oxyfluorfen & 70.1 & 16 May & 23 May & 31 May & 6 June \\
\hline \multicolumn{6}{|l|}{ Oakes 2008} \\
\hline \multicolumn{6}{|l|}{ Pre-emergence } \\
\hline DCPA & 8405 & 1 May & & & \\
\hline Pendimethalin & 798.6 & 1 May & & & \\
\hline \multicolumn{6}{|l|}{ Post-emergence } \\
\hline Bromoxynil & 70.1 & 16 May & 26 May & 3 June & 9 June \\
\hline Oxyfluorfen & 70.1 & 16 May & 26 May & 3 June & 9 June \\
\hline
\end{tabular}

\subsection{General Procedures}

Onion were seeded at a population of 617,760 and 704,250 seeds/ha on 20 April 2007 and 23 April 2008 , respectively and grown in accordance to production recommendations, including soil fertility, overhead irrigation, as well as insect and disease management practices [12]. Five in-season nitrogen applications (32\% urea-ammonium nitrate) were applied at 2 weeks intervals, beginning at the onion three-leaf growth stage. During the 2007 growing season, the fungal leaf disease purple blotch (causal agent, Alternaria porri) was detected and controlled with applications of the fungicides azoxystrobin (Quadris; Syngenta Crop Protection LLC, Greensboro, NC, USA) at $146 \mathrm{~g}$ ai ha ${ }^{-1}$ and pyraclostrobin (Headline; BASF Corporation, Research Triangle Park, NC, USA) at $219 \mathrm{~g}$ ai ha ${ }^{-1}$ in rotation. Onion fly maggots (Delia antique) were also detected in 2007 and were controlled with chlorpyrifos (Lorsban; Dow AgroSciences, Indianapolis, IN, USA) at $1120 \mathrm{~g}_{\text {ai ha }}{ }^{-1}$. In 2008, fungicide applications of azoxystrobin (146 $\left.\mathrm{g} \mathrm{ha}^{-1}\right)$ and pyraclostrobin $\left(219 \mathrm{~g} \mathrm{ha}^{-1}\right)$ were made in rotation, similar to that denoted for 2007.

Grass weeds were controlled as needed with clethodim (Select; Valent USA Corp, Walnut Creek, CA, USA) at $140 \mathrm{~g}_{\text {ai ha }}{ }^{-1}$ plus a crop oil concentrate (Herbimax; Loveland Products Inc, Greeley, CO, USA) at $1 \% v / v$. All treatments received a POST application of bromoxynil and oxyfluorfen at $280 \mathrm{~g} \mathrm{ha}^{-1}$, and $1120 \mathrm{~g} \mathrm{ha}^{-1}$, respectively, at the onion two- to three-leaf growth stage for mid-season weed control. If onion in the POST herbicide treatments reached the two- to three-leaf growth stage before micro-rate applications were completed, the mid-season application was delayed one week after the last micro-rate application. This occurred in 2007. Fertilizer, fungicide, and standard herbicide applications were made with a tractor mounted sprayer equipped with TeeJet 8002 flat-fan nozzles, spaced at $48 \mathrm{~cm}$ along a $2.8-\mathrm{m}$-wide boom; the sprayer was calibrated to deliver $170 \mathrm{~L} \mathrm{ha}^{-1}$.

Three broadleaf weed species, common lambsquarters (Chenopodium album), redroot pigweed (Amaranthus retroflexus), and hairy nightshade (Solanum physalifolium) were evaluated. Broadleaf weed control was evaluated by counting plants within a $1 \mathrm{~m}^{2}$ quadrate in the onion row $7 \mathrm{~d}$ after each micro-rate herbicide application, but prior to the sequential application.

Onion bulbs were hand harvested, allowed to cure, and then graded according to the United States Department of Agriculture's (USDA) standards as cull, small, medium, and large [13]. Bulbs were harvested from each middle two paired-rows on 5 September 2007 and 24 September 2008; harvested area was equal to $2.5 \mathrm{~m}^{2}$. The USDA standard diameters of grades were: cull, less than 
$2.5 \mathrm{~cm}$; small, $2.5 \mathrm{~cm}$ to $5.7 \mathrm{~cm}$; medium, $5.7 \mathrm{~cm}$ to $7.6 \mathrm{~cm}$; and large, greater than $7.6 \mathrm{~cm}$. Split and diseased bulbs were graded as culls, regardless of diameter.

\subsection{Statistical Analysis}

Data were statistically analyzed using two-way analysis of variance using the Mixed Procedure of SAS (version 9.1.3, SAS Institute Inc., Cary, NC, USA) with an alpha value of 0.05. Each environment was analyzed separately to test for homogeneity of mean square errors; environments were combined and analyzed when appropriate. The hand-weeded check was not included with the statistical analysis because onion were injured during the weed removal process and resulted in low yields. In the past, hand-weeding was initiated prior to onion emergence and hypothesized that this procedure reduced yield [14]. Low onion yield, regardless of when hand-weeding was initiated, indicated the difficulty of using hand-weeding for weed control in direct-seeded onion.

\section{Results and Discussion}

\subsection{Onion Emergence}

There was no tillage by herbicide interaction or differences between tillage or herbicide treatments for onion stand counts. This was expected as the onion double-rows were within similar soil conditions for the two tillage treatments. Pendimethalin has PRE application restrictions, especially if cool, rainy weather is expected, but has been shown to be very safe on onion in all types of situations when label restrictions are followed [15].

\subsection{Common Lambsquarters Control}

There was no tillage by herbicide interaction on common lambsquarters density for the first three weeks of evaluation. However, fewer common lambsquarters were associated with strip tillage (6 plants $\left.\mathrm{m}^{-1}\right)$ compared to conventional tillage $\left(11\right.$ plants $\left.\mathrm{m}^{-1}\right)$ at one week after the first micro-rate herbicide application (data not shown). Crop residue remaining on the soil surface in strip-tilled plots may have reduced weed seed germination and emergence. Crop residue has been shown to shade weed seeds, inhibiting germination [16]. It has also been shown that reduced soil disturbance in strip tillage systems increased mortality of common lambsquarters seeds via predation and desiccation [9].

Herbicide efficacy differed among years for common lambsquarters at one week after the second micro-rate herbicide application (1WA2A) and one week after the third micro-rate herbicide application (1WA3A) (Table 2). During 2007, pendimethalin was not as effective at controlling common lambsquarters 1WA2A and 1WA3A compared to the other herbicide treatments. Clough and Ball [17] reported that a PRE herbicide application of DCPA was more effective for early control of common lambsquarters than pendimethalin in dry bulb onion production. In addition, POST herbicides at 1WA3A provided better common lambsquarters control than pendimethalin and DCPA, and similar common lambsquarters control as the standard herbicide. The POST herbicide (oxyfluorfen and bromoxynil) controlled successive common lambsquarters flushes due to the second and third application timing. The common lambsquarters population was low in 2008 and thus densities did not differ among herbicide treatments.

One week after the fourth micro-rate herbicide application (1WA4A), there was an interaction between herbicide and tillage for common lambsquarters densities (Table 3). More common lambsquarters plants were in the conventional tillage plots treated with oxyfluorfen than any other tillage and herbicide treatment combination. Greater common lambsquarters control was expected with bromoxynil compared to oxyfluorfen as common lambsquarters is listed as a most susceptible broadleaf weed species on the bromoxynil label [18]. In 2007, PRE treatments received the standard mid-season herbicide application when POST treatments received their fourth micro-rate application, since onion reached the leaf-stage for the mid-season tank-mix. Thus, most of the common lambsquarters that 
escaped the PRE herbicide treatments (Table 2) were controlled, while later emerging common lambsquarters in the conventional tillage treatment were not controlled by oxyfluorfen.

Table 2. Common lambsquarters (Chenopodium album), redroot pigweed (Amaranthus retroflexus), and hairy nightshade (Solanum physalifolium) densities following herbicide applications at Oakes, ND, USA, during 2007 and 2008.

\begin{tabular}{|c|c|c|c|c|c|c|}
\hline \multirow[b]{2}{*}{ Treatment } & \multicolumn{2}{|c|}{ Common Lambsquarters } & \multicolumn{2}{|c|}{ Redroot Pigweed } & \multicolumn{2}{|c|}{ Hairy Nightshade } \\
\hline & \multicolumn{2}{|c|}{ - plants. $\mathrm{m}^{-2}-$} & \multicolumn{2}{|c|}{ - plants. $\mathbf{m}^{-2}-$} & \multicolumn{2}{|c|}{ - plants $\mathrm{m}^{-2}-$} \\
\hline 1 WA1A ${ }^{z}$ & & & & & & \\
\hline Pendimethalin & $14 \mathrm{a}^{\mathrm{x}}$ & $8 \mathrm{a}$ & $23 \mathrm{a}$ & $0 \mathrm{a}$ & $135 \mathrm{a}$ & $37 \mathrm{~b}$ \\
\hline DCPA & $4 \mathrm{~b}$ & $14 \mathrm{a}$ & $19 a$ & $0 \mathrm{a}$ & $110 \mathrm{a}$ & $75 \mathrm{a}$ \\
\hline Oxyfluorfen & $4 \mathrm{~b}$ & $20 \mathrm{a}$ & $1 \mathrm{~b}$ & $0 \mathrm{a}$ & $19 \mathrm{~b}$ & $12 \mathrm{c}$ \\
\hline Bromoxynil & $0 \mathrm{~b}$ & $6 \mathrm{a}$ & $1 \mathrm{~b}$ & $0 \mathrm{a}$ & $18 \mathrm{~b}$ & $20 \mathrm{bc}$ \\
\hline Grower Standard y & $8 \mathrm{~b}$ & 5 a & $27 \mathrm{a}$ & $0 \mathrm{a}$ & $113 \mathrm{a}$ & $54 \mathrm{ab}$ \\
\hline \multicolumn{7}{|l|}{ 1WA2A } \\
\hline Pendimethalin & $11 \mathrm{a}$ & $0 \mathrm{a}$ & $26 \mathrm{a}$ & $0 \mathrm{~b}$ & $100 \mathrm{a}$ & $53 \mathrm{~b}$ \\
\hline DCPA & $7 \mathrm{ab}$ & $0 \mathrm{a}$ & $15 \mathrm{a}$ & $3 b$ & $50 \mathrm{~b}$ & $132 \mathrm{a}$ \\
\hline Oxyfluorfen & $0 \mathrm{~b}$ & $0 \mathrm{a}$ & $0 \mathrm{~b}$ & $35 \mathrm{a}$ & $0 \mathrm{c}$ & $4 \mathrm{~b}$ \\
\hline Bromoxynil & $0 \mathrm{~b}$ & $0 \mathrm{a}$ & $0 \mathrm{~b}$ & $27 \mathrm{ab}$ & $3 c$ & $11 \mathrm{~b}$ \\
\hline Grower Standard & $8 \mathrm{ab}$ & $0 \mathrm{a}$ & $22 \mathrm{a}$ & $0 \mathrm{~b}$ & $35 \mathrm{~b}$ & 126 a \\
\hline \multicolumn{7}{|l|}{ 1WA3A } \\
\hline Pendimethalin & $14 \mathrm{a}$ & $1 \mathrm{a}$ & $42 \mathrm{a}$ & $0 \mathrm{a}$ & $86 a$ & $41 \mathrm{bc}$ \\
\hline DCPA & $3 a$ & $1 \mathrm{a}$ & $22 \mathrm{a}$ & $0 \mathrm{a}$ & $73 \mathrm{a}$ & $116 \mathrm{a}$ \\
\hline Oxyfluorfen & $3 a$ & $12 \mathrm{a}$ & $0 \mathrm{~b}$ & $0 \mathrm{a}$ & $1 \mathrm{~b}$ & $0 \mathrm{c}$ \\
\hline Bromoxynil & $0 \mathrm{a}$ & $7 \mathrm{a}$ & $0 \mathrm{~b}$ & $0 \mathrm{a}$ & $0 \mathrm{~b}$ & $3 c$ \\
\hline Grower Standard & $3 \mathrm{a}$ & $0 \mathrm{a}$ & $35 \mathrm{a}$ & $0 \mathrm{a}$ & $73 \mathrm{a}$ & $97 \mathrm{ab}$ \\
\hline \multicolumn{7}{|l|}{ 1WA4A } \\
\hline Pendimethalin & $1 \mathrm{a}$ & $1 \mathrm{a}$ & $3 a$ & $0 \mathrm{a}$ & $0 \mathrm{a}$ & $33 \mathrm{~b}$ \\
\hline DCPA & $0 \mathrm{a}$ & $0 \mathrm{a}$ & $1 \mathrm{a}$ & $0 \mathrm{a}$ & $0 \mathrm{a}$ & $50 \mathrm{ab}$ \\
\hline Oxyfluorfen & $3 \mathrm{a}$ & $15 \mathrm{a}$ & $0 \mathrm{a}$ & $0 \mathrm{a}$ & $1 \mathrm{a}$ & $0 \mathrm{c}$ \\
\hline Bromoxynil & $0 \mathrm{a}$ & $4 \mathrm{a}$ & $0 \mathrm{a}$ & $0 \mathrm{a}$ & $1 \mathrm{a}$ & $0 \mathrm{c}$ \\
\hline Grower Standard & $0 \mathrm{a}$ & $0 \mathrm{a}$ & $3 a$ & $0 \mathrm{a}$ & $0 \mathrm{a}$ & $54 \mathrm{a}$ \\
\hline
\end{tabular}

${ }^{\mathrm{z}} 1 \mathrm{WA} 1 \mathrm{~A}=$ one week after first micro-rate herbicide application, 1WA2A = one week after second micro-rate herbicide application, 1WA3A = one week after third micro-rate herbicide application, 1WA4A = one week after fourth micro-rate herbicide application; ${ }^{y}$ Standard grower practice of herbicide weed management, DCPA (PRE) followed by a POST application at onion three-leaf growth stage of bromoxynil and oxyfluorfen; ${ }^{\mathrm{x}}$ Means for each application timing and year followed by the same lower case letter are not significantly different according to Fisher's Protected LSD $(p<0.05)$.

Table 3. Common lambsquarters (Chenopodium album) and hairy nightshade (Solanum physalifolium) densities as affected by herbicide and tillage averaged over years at Oakes, ND, USA.

\begin{tabular}{|c|c|c|c|c|}
\hline \multirow{3}{*}{ Herbicide } & \multicolumn{2}{|c|}{ Common Lambsquarters $^{z}$} & \multicolumn{2}{|c|}{ Hairy Nightshade ${ }^{y}$} \\
\hline & \multirow{2}{*}{\multicolumn{2}{|c|}{$\longrightarrow$ (plants $\left.\mathrm{m}^{-2}\right)$}} & & Conventional \\
\hline & & & \multicolumn{2}{|c|}{$\longrightarrow$ (plants $\mathrm{m}^{-2}$ ) } \\
\hline Pendimethalin & $0 b^{x}$ & $3 \mathrm{~b}$ & $43 \mathrm{bcd}$ & $128 \mathrm{a}$ \\
\hline DCPA & $0 \mathrm{~b}$ & $0 \mathrm{~b}$ & $92 \mathrm{ab}$ & $94 \mathrm{ab}$ \\
\hline Oxyfluorfen & $4 \mathrm{~b}$ & $14 \mathrm{a}$ & $12 \mathrm{e}$ & 19 cde \\
\hline Bromoxynil & $3 b$ & $1 \mathrm{~b}$ & 16 de & $22 \mathrm{c}$ \\
\hline Std. herbicide & $0 \mathrm{~b}$ & $0 \mathrm{~b}$ & $52 \mathrm{bcd}$ & $77 \mathrm{abc}$ \\
\hline
\end{tabular}

${ }^{\mathrm{z}}$ Plant densities one week after fourth micro-rate herbicide application; ${ }^{\mathrm{y}}$ Plant densities one week after first micro-rate herbicide application; ${ }^{\mathrm{x}}$ Means for each weed species followed by the same lower case letter are not significantly different according to Fisher's Protected LSD $(p \leqslant 0.05)$. 


\subsection{Redroot Pigweed Control}

There was no tillage by herbicide interaction on redroot pigweed density for the four weeks of evaluation. Herbicide efficacy differed among years for redroot pigweed (Table 2). During 2007, POST herbicide treatments decreased redroot pigweed densities 1WA1A, 1WA2A, and 1WA3A in comparison to PRE herbicide treatments. Reduced redroot pigweed control with PRE herbicides in 2007 was attributed to a rainfall event five days following application. The PRE herbicides were applied on 30 April and $15 \mathrm{~cm}$ of rain fell over a two day period starting 4 May, which may have caused more herbicide to be lost through the soil profile [19].

Redroot pigweed densities in 2008 were minimal 1WA1A compared to the previous year. However, a flush of redroot pigweed emerged 1WA2A. At this time, similar redroot pigweed densities occurred in both POST herbicide treatments; however, redroot pigweed control was less with oxyfluorfen compared to the other herbicide treatments (Table 2). This flush was controlled with the third POST micro-rate herbicide application and redroot pigweed was not observed 1WA3A.

\subsection{Hairy Nightshade Control}

Hairy nightshade density varied among herbicide and tillage combinations only at 1WA1A (Table 3). Hairy nightshade density was lower when oxyfluorfen and bromoxynil were applied in either strip tillage or conventional tillage in comparison to DCPA or pendimethalin. However, when strip tillage was used, the highest plant density occurred where pendimethalin was applied, while under conventional tillage, the highest plant density was when DCPA was applied. Spring tillage practices have been shown to initiate hairy nightshade germination and increase emergence [20]. They found at least an $88 \%$ reduction in hairy nightshade populations when spring tillage was eliminated, suggesting that reduced tillage systems may reduce hairy nightshade pressure.

Herbicide efficacy differed among years for hairy nightshade evaluations 1WA2A and 1WA4A (Table 2). During 2007, hairy nightshade densities at 1WA2A were lowest in POST herbicide treated plots and greatest in PRE herbicide treated plots. No successive flushes of hairy nightshade occurred following 1WA2A. A similar pattern was seen during the 2008 growing season; namely, hairy nightshade densities were lower in POST herbicide treatments. Ransom et al. [21] reported more effective nightshade control in onion with PRE pendimethalin than DCPA. However, this contradicted the 2007 results where nightshade was more effectively controlled with DCPA than pendimethalin. The inconsistency of data from 2007 to 2008 was attributed to poor hairy nightshade control by either herbicide. Smith et al. [22] reported that both herbicides provided only partial hairy nightshade control in onion.

At 1WA4A in 2007, the mid-season herbicide application occurred the previous week for the PRE treatments, thus all herbicide treatments had similar hairy nightshade densities (Table 2). However, in 2008, hairy nightshade densities were lowest in POST herbicide treated plots and similar to results reported at 1WA2A.

\subsection{Onion Yield}

Results of homogeneity of error mean squares tests allowed for combined data analysis across growing seasons, but because the interaction between tillage and year was significant, discussion of growing seasons will remain separated. There was no tillage by herbicide interaction for onion grade and yield. Onion grade and yield did not differ among herbicide treatments during either growing season (data not shown). In 2007, most of the weeds that escaped the early-season herbicide treatments were either controlled or defoliated by the mid-season bromoxynil and oxyfluorfen tank-mix application, while in 2008; weed densities were low, especially for common lambsquarters and fewer weeds escaped the herbicide treatments and were controlled with the mid-season herbicide application. In both cases, those individuals that remained in the plots did not impact bulb diameter or overall yield. The lack of onion grade and yield differences among herbicide treatments suggests that even 
though the post-emergence herbicide treatments generally provided better early-season broadleaf control compared to the pre-emergence treatments, this did not compensate for the additional costs associated with multiple spray applications and the increased weather risk associated with the need for four timely spray applications. The lack of onion grand and yield differences among herbicide treatments were contrary to those reported by Loken and Hatterman-Valenti [11], but do reinforce the importance of weed control at the onion two- and three-leaf stage (mid-season herbicide application) and prior to the onion bulbing stage.

In 2007, tillage affected onion yield as well as bulb diameter (Table 4). More large onion bulbs were produced under strip tillage compared to conventional tillage. This resulted in greater marketable and total yields compared to conventional tillage. Similar trends were also observed in 2008; however, the differences were not significant. There were more small-diameter onion with conventional tillage, but this did not influence marketable or total yields. Evans et al. [23] reported a 17\% greater sugarbeet (Beta vulgaris L.) yield in only one year with strip tillage, which they attributed the standing straw stubble that protected sugarbeet seedlings from blowing soil during a spring wind storm. Haramoto and Brainard [24] reported that in row soil moisture was higher season-long in strip tillage compared with conventional tillage, but that tillage did not influence cabbage marketable yield. However, the cabbage were transplanted and thus less sensitive to soil moisture differences than a seeded crop. Both factors (reduced wind erosion and increased soil moisture) may have contributed to the increased onion yield with strip tillage, but it is more likely that the higher onion yield was a result of an increase in soil moisture with strip tillage [5].

Table 4. Onion (Allium cepa) grade and yield as affected by tillage and year averaged over herbicide treatments at Oakes, ND, USA.

\begin{tabular}{llllll}
\hline \multirow{2}{*}{ Year } & \multicolumn{5}{c}{ Onion Yield $^{\mathbf{z}}$} \\
\cline { 2 - 6 } & \multicolumn{1}{c}{ Small } & Medium & Large & Marketable & Total \\
\cline { 2 - 6 } 2007 & $10.8 \mathrm{a}^{\mathrm{y}}$ & $32.8 \mathrm{a}$ & $49.3 \mathrm{a}$ & $82.1 \mathrm{a}$ & $92.9 \mathrm{a}$ \\
$\quad$ Strip tillage & $14.6 \mathrm{a}$ & $33.1 \mathrm{a}$ & $31.9 \mathrm{~b}$ & $64.9 \mathrm{~b}$ & $79.2 \mathrm{~b}$ \\
$\quad$ Conventional & & & & & \\
2008 & $7.6 \mathrm{~b}$ & $25.6 \mathrm{a}$ & $25.3 \mathrm{a}$ & $50.8 \mathrm{a}$ & $58.4 \mathrm{a}$ \\
Strip tillage & $10.2 \mathrm{a}$ & $24.6 \mathrm{a}$ & $22.1 \mathrm{a}$ & $46.7 \mathrm{a}$ & $56.9 \mathrm{a}$ \\
Conventional &
\end{tabular}

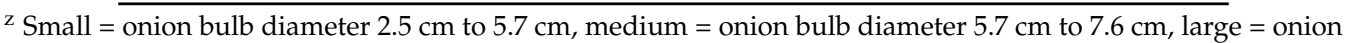
bulb diameter greater than $7.6 \mathrm{~cm}$, marketable $=$ onion bulb diameter $\geqslant 5.7 \mathrm{~cm}$ and not split or diseased; ${ }^{y}$ Means within each column and year followed by the same letter are not significantly different according to Fisher's Protected LSD $(p \leqslant 0.05)$.

\section{Conclusions}

There were no differences between tillage or herbicide treatments for onion stand counts. Post-emergence herbicides generally provided greater early-season common lambsquarters, redroot pigweed, and hairy nightshade control than pre-emergence herbicide treatments, but the greater early-season broadleaf weed control from multiple spray applications did not increase onion grade or yield. More large onion bulbs were produced under strip tillage compared to conventional tillage in 2007. This resulted in greater marketable and total yields under strip tillage compared to conventional tillage. Results support implementing strip tillage in seeded onion production, especially when growing conditions are conducive to higher yields. The use of strip tillage in onion production may provide an alternative to using a barley companion crop since onion can be readily planted within the tilled strip and crop residue remains undisturbed on more than half the area to reduce wind erosion. In addition, the use of strip tillage did not interfere with either PRE or POST herbicide systems used to provide early-season broadleaf weed control.

Acknowledgments: Partial funding for this research was provided by SBARE, new and emerging crops. 
Author Contributions: H. Hatterman-Valenti conceived and designed the experiments; S. Gegner-Kazmierczak performed the experiments; S. Gegner-Kazmierczak analyzed the data; H. Hatterman-Valenti contributed reagents/materials/analysis tools; S. Gegner-Kazmierczak wrote the paper; H. Hatterman-Valenti edited and rewrote paper.

Conflicts of Interest: The authors declare no conflict of interest.

\section{References}

1. Naeve, L. Agriculture marketing resource center: Onions. 2015. Available online: http://www.agmrc.org/ commodities_products/vegetables/onions/ (accessed on 1 October 2015).

2. [NOA] National Onion Association. About onions: Bulb onion production. 2011. Available online: http:/ /www.onions-usa.org/ (accessed on 1 October 2015).

3. Brewster, J.L. Onions and Other Vegetable Alliums; CAB International: Wallingford, UK, 2008; p. 1994.

4. Gruszecki, R.; Tendaj, M. Effect of cultivation method on the earliness and structure of onion yield. Veg. Crops Res. Bull. 2001, 54, 43-48.

5. Kesik, T.; Blazewicz-Wozniak, M. Growth and yielding of onion under conservation tillage. Veg. Crops Res. Bull. 2009, 70, 111-123. [CrossRef]

6. Greenland, R. Optimum height at which to kill barley used as a living mulch in onions. HortScience 2000, 35, 853-855.

7. Hatterman-Valenti, H.M.; Hendrickson, P.E. Companion crop and planting configuration effect on onion. HortTechnology 2006, 16, 12-15.

8. Unger, P.W.; Schomberg, H.H.; Dao, T.H.; Jones, O.R. Tillage and crop residue management practices for sustainable dryland farming systems. Ann. Arid Zone 1997, 36, 209-232.

9. Clements, D.R.; Benoit, D.L.; Murphy, S.D.; Swanton, C.J. Tillage effects on weed seed return and seedbank composition. Weed Sci. 1996, 44, 314-322.

10. Hoyt, G.D. Tillage and cover residue effects on vegetable yields. HortTechnology 1999, 9, 351-358.

11. Loken, J.R.; Hatterman-Valenti, H.M. Multiple applications of reduced-rate herbicides for weed control in onion. Weed Technol. 2010, 24, 153-159. [CrossRef]

12. Engel, D. Midwest Vegetable Production Guide for Commercial Growers. Relative effectiveness of herbicides for vegetable crops. 2015. Available online: http://mwveguide.org/53_WeedManagement.pdf (accessed on 1 October 2015).

13. [USDA] United States Department of Agriculture. United States standards for grades of onions (other than Bermuda-Granex-Grano and Creole type). 1997. Available online: http://www.ams.usda.gov/ AMSv1.0/getfile?dDocName=STELPRDC5050312 (accessed on 1 October 2015).

14. Schumacher, C.E.; Hatterman-Valenti, H.M. Effect of dose and spray volume on early-season broadleaved weed control in Allium using herbicides. Crop Prot. 2007, 26, 1178-1185. [CrossRef]

15. Zandstra, B. Onion pre-emergence weed control in 2015. Michigan State University Extension News_Vegetable production digest. 2015. Available online: http://msue.anr.msu.edu/news/ onion_pre_emergence_weed_control_in_2015 (accessed on 1 October 2015).

16. Buhler, D.D. Effects of tillage and light environment on emergence of 13 annual weeds. Weed Technol. 1997, 11, 496-501.

17. Clough, G.; Ball, D.A. Dehy onion herbicide evaluation. In Horticulture Weed Control 1995 Report; Hermiston Agricultural Research \& Extension Center: Hermiston, OR, USA, 1996; pp. 61-66.

18. Anonymous. Buctril®Herbicide Product Label. Bayer Crop Science. 2005. Available online: http:/ / www.cdms.net/LDat/ld405002.pdf (accessed on 1 October 2015).

19. [NDAWN] North Dakota Agricultural Weather Network. Daily Data Table. 2014. Available online: http://ndawn.ndsu.nodak.edu/weather-data-daily.html (accessed on 1 October 2015).

20. Peachey, B.E.; William, R.D.; Mallory-Smith, C. Effect of spring tillage sequence on summer annual weeds in vegetable row crop rotations. Weed Technol. 2006, 20, 204-214. [CrossRef]

21. Ransom, C.V.; Rice, C.A.; Ishida, J.K. Preemergence herbicides for weed control in onion. OSU Agricultural Expt. Station-Special Report 1055. 2004, pp. 91-96. Available online: http://www.cropinfo.net/ AnnualReports/2003/2003-16-OnionPreemergence.php (accessed on 1 October 2015). 
22. Smith, R.; Fennimore, S.A.; Orloff, S.; Poole, G.J. UC Pest Management Guidelines. Susceptibility of weeds to herbicide control in onion and garlic. 2010. Available online: http://www.ipm.ucdavis.edu/ PMG/r584700311.html (accessed on 1 October 2015).

23. Evans, R.G.; Stevens, W.B.; Iversen, W.M. Development of strip tillage on sprinkler irrigated sugarbeet. Appl. Eng. Agric. 2010, 26, 59-69. [CrossRef]

24. Haramoto, E.R.; Brainard, D.C. Strip tillage and oat cover crops increase soil moisture and influence N mineralization patterns in cabbage. HortScience 2012, 47, 1596-1602.

(C) 2016 by the authors; licensee MDPI, Basel, Switzerland. This article is an open access article distributed under the terms and conditions of the Creative Commons by Attribution (CC-BY) license (http://creativecommons.org/licenses/by/4.0/). 